\title{
Japan anticipates green light for nuclear plants
}

Japan is edging closer to launching its controversial nuclear-fuel recycling system; the first local approval for a power plant using recycled mixed-oxide fuel (MOX) looks almost certain.

The Japanese government decided in 1997 to promote the use of MOX - a mix of plutonium and uranium produced by recycling spent nuclear fuel. But progress in adopting the fuel has been slow, due to a fatal accident at a nuclear power reactor, scandals involving falsified inspection data, and strong resistance from local people over safety concerns.

But the first green light for using MOX, expected to come from the conservative government of Saga prefecture on the southern island of Kyushu, could speed the introduction of such plants around the nation. It could also help the government justify the nearly $¥ 2$ trillion (US $\$ 17.2$ billion) it is spending on a fuelrecycling plant in Rokkasho village in the northern prefecture of Aomori. This is scheduled to go into operation next year.
After a prefectural assembly signalled its approval last month, local officials are likely to endorse the plan to use MOX at one of four nuclear-power reactors in the town of Genkai before the assembly closes on $23 \mathrm{March}$. They will then make a formal agreement with a local power company, which is expected to be confirmed within the next few months. It is hoped that the plant will be operating by 2010 , initially using MOX bought from France or Britain.

The agreement will be a huge relief for the government, as recycling nuclear fuel is at the core of its long-term energy policy. Japan has few natural energy resources. And because it currently gets around a third of its energy from nuclear power, it also needs a way to get rid of the nudear waste produced. The government wants to replace uranium with MOX at 16 to 18 of Japan's 52 nudear power plants by 2010 .
Critics argue that the plutonium in recycled fuel would release more radiation than conventional fuel in the event of an accident, and would be a target for terrorists. "Security measures at Japanese nuclear power plants are not nearly as great as they should be," says Edwin Lyman, a physicist at the Union of Concerned Scientists in Cambridge, Masssachusetts.

France, Germany, Switzerland and Belgium all run MOX plants, with much of the fuel produced at the Britain's plants in Sellafield. All but France have decided to stop their operations. But many believe Saga officials are being encouraged partly by the US government's announcement on 6 February of a $\$ 250$-million plan to resume research of reprocessing spent nudear fuel, a major reversal of a 1970 s policybanning the use of such fuel.

Ichiko Fuyuno 